\title{
PREVENTIVE EFFORTS OF CORRUPTION THROUGH RELIGIOUS MORAL REINFORCEMENT AND REPRESIVE EFFORTS THROUGH THE IMPLEMENTATION OF THE REVERSAL BURDEN PROOF IN ERADICATING CORRUPTION IN INDONESIA
}

\author{
Sulistyowati \\ Muria Kudus University \\ sulistyowati@umk.ac.id
}

\begin{abstract}
Corruption in Indonesia occurs systematically and extends not only state finances, but also has increased rights and space for society, but also needs to be done in the normal way. Thus, the eradication of corruption must be done in a special way through moral reinforcement and repressive efforts through the application of reversed proof. One way that can be done to resolve corruption, is to take preventive action as a preventive action and law enforcement action, in a repressive way. The spiritual spiritual service is the guidance, the life to determine the attitude and purpose of life. Religious spirituality as well as a solid foundation for determining the direction of life and as the ideal ideal to guide and direct, every human desire and passion
\end{abstract}

Keywords: Eradicating Corruption; Preventive Effort; Repressive Effort.

\section{A. INTRODUCTION}

Korupsi in Bahasa Indonesia comes from the word corruption, based on Webster's New American Dictionary, 1985, it literally means weathered, destructive, impure, rotten, bad or rancid. While the New World Dictionary of American Language, 1998, defines the situation to be bad, evil and reprehensible behavior, moral evil, violations of religious norms, bribery and dishonesty.

Corruption is an extraordinary crime, it is a criminal offense, an unlawful act, an ethical, moral, and an act of haram according to religion. Corruption acts will undermine the state's finances and worsen the economy of society, so that it interferes with economic growth, and will undermine the spiritual morals. People who commit corruption, consciously or unconsciously, will embrace religious moral values. This is because corruption acts no longer use the foundation of the general norm let alone the specific norms, such as religious spiritual norms.

Terminology of corruption is an act of abuse of power, authority and/or trust for personal interest, the interests of the parties and or to enrich themselves and/or enrich other.

Corruption is a misuse of power and misappropriation of authority, arising from a lack of control over the power it possesses, and the opening of opportunities to divert it. In addition, the fragility of religious moral ethics and religious spiritual loss are also a factor driving someone to do corruption. In addition, the aforementioned, corruption is also driven by personal motives, for example: wanting to live rich in an instant way, to pursue recognition of socioeconomic status. ${ }^{1}$

1 Pulungan Suyuthi, 2006, Korupsi Di Negeri Berpenduduk Mayoritas Muslim : Suatu Kajian Tentang Sistem Politik, Gama Media, Yogyakarta, p.205. 
The ideals and hopes and efforts to make Indonesia clean corruption, is a spirit to fight corruption, whether it is done preventively or repressively. Corruption is a corporate crime and an extraordinary crime, then the eradication of corruption must also be done in extraordinary ways as well. Fighting corrupt crime is not only with repressive law enforcement with high imprisonment sanctions imposed, but also must be holistic, comprehensive, simultaneous and simultaneous and sustainable. Comprehensive, integrated and simultaneous and continuous holistic fighting is the most effective and efficient way to reduce the rate growth of corruption, and it is expected to be able to make Indonesia clean of corruption.

Corruption has taken place in all areas of governance, whether it be the executive, the legislature, or the judiciary, which is known for the widespread bureaucratic corruption of corruption committed by the people who hold the institutional powers of the state, both executive, legislative and judiciary. ${ }^{2}$ The widespread practice of corruption in various governments has disrupted the wheels of government and generated enormous losses to the state's finances and economies. Seeing the losses incurred, then corruption can be categorized as regulatory offences or offenses that prevent and even seize the results of government efforts in the prosperity of their people. ${ }^{3}$ Like disease, corruption will always exist among the people, but this sad disease does not make people stop trying to reduce the disease. Nor should it

2 Amir Syamsuddin, 2008, Integritas Penegak Hukum, Hakim, Jaksa, Polisi, dan Pengacara, Kompas, Jakarta, p.135

3 Junaedi dalam M.Akil Mochtar, 2006, Memberantas Korupsi Efektivitas Sistem Pembalikan Beban Pembuktian Dalam Gratifikasi, Q-Communication, Jakarta, p.10 necessarily paralyze attempts to exterminate. Combating corruption is a set of actions to prevent and tackle corruption (through coordination, supervision, monitoring, investigation, investigation, prosecution and examination in court) with community participation based on prevailing laws and regulations. ${ }^{4}$

One way that can be done to combat corruption comprehensively is to take preventive measures and enforcement actions, by repressive measures. One of the preventive measures for the prevention of corruption is by raising religious spiritual morals, every Indonesian People in general and Officials in particular. The moral quality of religious spirituality will affect and color each person's actions. Religious spiritual morals are guidance, life to determine attitudes and purpose of life. Religious spirituality as well as a solid foundation for determining the direction of life as well as the ideal for guiding and directing, every human's desire and passion.

The law enforcement action for corruption is a repressive action, until now it has not shown maximum results. This is due to the Attitudes of Law Enforcement Officials who do not yet have a moral commitment to take responsibility for eradicating corruption. This situation is evidenced by the number of law enforcement officers caught red-handed, who accepts bribes in law enforcement process in the eradication of corruption. The Proof of Evidence Law for corruption also has not provided the Defendant with the burden of proof, and the burden of proof must still be the responsibility of the Prosecutor. Such Evidence Proof Law is still conventional and makes the defendant has no responsibility, to prove that all his

4 Robert Klitgaard, 2001, Membasmi Korupsi, second edition, Yayasan Obor Indonesia, Jakarta, p.10. 
property is not from the proceeds of corruption. While the Prosecutor must work hard to prove all the indictments that the Defendant's property is true factually the result of a criminal act of corruption.

\section{B. DISCUSSION}

\section{Preventive Efforts to Prevent Corruption in Indonesia}

The corruption eradication program must be conducted simultaneously and sustainable, integrated and comprehensively. Eradication in an integrative and comprehensive mean to eradicate corruption is not effective enough if only done by taking one movement that is repressive law enforcement only. To be more effective, the eradication of corruption must be done simultaneously and sustainable in addition to repressive also preventively.

Increasing spiritual is a preventive action effort, which can be done to prevent intent and desire for corruption. Moral teachings of religion must color the spirituality of each people, it is used to be able to distinguish what actions that violate the norms of religion and which act that tarnished the faith and moral ethics of someone. The ethical and spiritual moral measures are more on the issue of conscience. Religious spiritual truth becomes the basic norm for good and bad, elegant and unflattering, lawful and haram, reward and sin and to determine ethical and unethical measures. The religious moral measure is sourced from Scripture also in the transformation of life often acculturates with the local wisdom culture of society. ${ }^{5}$

5 Muslich, 2004, Etika Bisnis Islami, Ekonisia-F.E.UII, Yogyakarta, P.2007.
Spiritual strengthening should not be interpreted only carrying ceremonial religious, but must be understood essentially and crystallize in the moral attitude of life behavior. Building religious spiritual qualities will be a major investment to prevent corruption, and it is the first door to eradicate corruption. Fighting corruption, by way of prevention, is actually assumed to be more efficient but less effective. Nevertheless, prevention remains a key determinant to suppress the rate of corruption. Thus, the actual act of preventing and prosecuting corrupt acts is one piece of currency, which each side becomes the determinant of value. ${ }^{6}$

In the perspective of social transformation, it is very possible to occur the condition of society, which seems to lose role models in social life. Such a condition would potentially lead to an anomalous role and social standing of Public Officials, which contradict the das sollen norm of religious spiritual ethics with das sein the factual conditions of life. ${ }^{7}$

The power of the spiritual role, to prevent corruption, must be done through the application of religious moral ethical values so that it becomes a spiritual power and no longer actualizes mere religious symbols and rituals. The value of a strong religious moral ethic is an indication of the quality of one's faith and at the same time a spiritual practice in practice.

Moral or mental cannot be separated from one's faith and morals. Faith will justify in the heart, utter with

6 Andi Hamzah, 2014, Perbandingan Pemberantasan Korupsi Di Berbagai Negara, Sinar Grafika, Jakarta, p.78.

7 Duski Ibrahim, 2006, Perumusan Fikih Anti Korupsi, Gama Media, Yogyakarta, p.161. 
the tongue and work with the body. The believers will not commit corruption. People who do not corrupt and are not tempted to corrupt, because he has a strong faith and the strong faith will be actualized in spiritual life of religion. ${ }^{8}$

A person's moral is also an important thing to determine the attitude of people whether to do corruption or not. This is because morality means a behavior, character and basic character. Morals will be firmly entrenched in the soul and become the personality of personality, and morals are deeds that are done with acceptable and without thinking (unthought). Thus good morality will make people do the actual and the best without any element of pretense. ${ }^{9}$

Religious Spiritual is a soul and religious spirit, which will direct and guide the thoughts, attitudes and actions of someone. Legal Philosophy Experts affirm that moral and law are two sides that must always coexist and complement each other to achieve the quality of life of people. According to Imanuel Kant, moral law is law in the true sense. Thus, it can be drawn the line of understanding, that the moral person is a person who has spiritual spirituality, with ethics and morals of quality faith, so as to be able to keep themselves from acts that violate the law, especially acts of corruption. With a good religious spiritual capital, it will maintain the self-behavior of corrupt practices, for it is believed that corruption not only violates the norms of state law but also violates the norms of religious law.

8 Heri Junaedi, 2006, Agama Melawan Budaya Korupsi, Gama Media, Yogyakarta, p.171-173.

9 Ibid. P.175.
Attitudes not to commit corruption with faith-based spiritual commitment will be a real form of corruption prevention. Preventive measures of corruption give efficient calculation though it is not necessarily effective. In a more effective prevention effort, it must be sustainable that there should be no interrupted generation to fight corruption altogether.

The goal of corruption eradication measures, preventively by raising religious spirituality can be scheduled for all levels of society. So do not just target potential Officials by using the authority to commit acts of corruption. This will give great hope that the preventive measures have a wide spectrum of targets, to enable Indonesia to be clean from corruption.

\section{Repressive Efforts to Eradicate Corruption in Indonesia}

The criminal act of corruption in Indonesia has now entered a quite dangerous phase, the stability of economic growth. In addition, it leads to no trust and low trust society to Officials and Power Holders, who have great potential for misusing their powers and position. Abuses of power and authority may be gratification acceptance and corruption, collusion and nepotism. The high number of Corruptors in Indonesia is known as the Religious State, because not all Power Officials in Indonesia have a high religious spiritual spirit. In addition, the Officials of the Holder of Power have not been able to understand the meaning of the Office as the Mandate of the Almighty. Such a situation, to be the main benchmark, whether corruption in Indonesia will be 
eradicated and Indonesia will be clean from corruption in 2020.

In addition to corrupt mental factors, the cause of the high number of Corrupt Officials is the Law of Proof of Corruption in Indonesia which is more in favor of the Defendant. The Law Enforcement System of Corruption in Indonesia, especially for Proof of Evidence Law is still on the side of the Defendant, as all burden of proof of corruption must be charged to the Prosecutor. So, the prosecutor who must work hard to prove the indictment to the Defendant is true and proven in the examination of the Corruption Court.

The fact mentioned above, actually does not need to happen and must be corrected in the application of Proof of Evaluation Procedure for criminal acts of corruption. This is a mistake in applying the Proof of Evaluation Law. Proof of corruption is not subject to the provision of Article 66 of the Criminal Procedure Code which states: "Suspect or Defendant is not burdened with proof", thus the proof is the duty of the Prosecutor who has indicted the Defendant.

Proof of corruption in Indonesia should be applied under the Law of Evidence Burden Evaluation or Reversal of Burden of Evidence (om kering van het bewijslast or shifting burden of proof /reversal burden of proof). As the basis of the law referred is the provision of Article $38 \mathrm{~B}$, Paragraph (1, 2, 3, 4, 5 \& 6) Law Number: 20 of 2001 on Amendment to Act No.31 Of 1999 on Corruption.

In the practice of proof, it turns out that the prosecutors who still have to prove their indictment, and the defendant is not asked to prove that the property owned is not the result of corruption. Usually in the Defense the Defendant or his Legal Counsel shall exercise his right to prove that the defendant did not commit a criminal act of corruption, as regulated in the provisions of Article 37, Paragraphs (1) and Article $37 \mathrm{~A}$, Paragraph (1, 2 \& 3): 20 of 2001 on Amendment to Act No.31 Of 1999 concerning the Criminal Act of Corruption.

The existence of the provisions of Article 37, Paragraphs (1) and Article $37 \mathrm{~A}$, Paragraphs $(1,2 \& 3)$, makes the Procedure Law of Reverse Evidence Load or Reversal System of Evidence Load (om kering van het bewijslast or shifting burden of proof/reversal burden of proof) is increasingly unclear. This is certainly related to the Government of Indonesia's Law Politics which is still very strongly controlled by the Legislator. There appears to be a political interest in the process of forming this law, thus obscuring and making ambiguities on the Probation Reversal System (om kering van het bewijslast or shifting burden of proof/reversal burden of proof). Political Law of the government from the stage of making, implementing and enforcing the law of corruption is strongly influenced by political interests, making it difficult to assess the good will of the Government and Legislators to combat corruption. According to Marwan Effendy, corruption in Indonesia enters the phase of the iceberg, because corruption is systematic, coordinated and sustainable with the ever-changing or changing models and modes.

In the beginning, when the draft amendment of Act No.31 Of 1999 (now already stipulated as Act No.20 of 2001 on Amendment to Act No.31 Of 1999 on Corruption), is in fact the main spirit 
that will scheduled for change is a section governing the provision of proof for the offense of corruption. The burden of proof is no longer the duty of the prosecutor who accused but should be the obligation of the Defendant to prove that he is not corrupt. Such proof is also commonly called Reversal Burden of Proof. The fact that the political will legislator has no vision to really intend to combat corruption, the article governing the reversal of the burden of proof, suddenly diverted and inserted the provisions of Article 37, Paragraph (1) and Article 37 A, Paragraph (1, 2 \& 3).

The reversal of the burden of proof can be realized in the Proof of Corruption Evidence Act, it can actually be used as a repressive tool for the Corruptors to think, because proving all their wealth is not from corruption is much more difficult and complicated, because it will involve the proof of data on the origin wealth.

In Malaysia, the reversal of the burden of proof has been done, and according to Baharuddin Lopa (Former Minister of Justice), Malaysia succeeded quite successfully in eradicating corruption by using the System of Burden Reversal of Evidence. The Probation Reversal Model in Malaysia is that the Prosecutor only proves a core part of the corruption offense, such as the offense of gratuity, the rest is selfcontained, thus the Prosecutor no longer needs to prove another offense which is the element of criminal act of corruption. So the element of giving is related to his position and contrary to his obligation, so that there are elements against the law, enriching themselves and/or others, there is loss of the state and the possessed property is the result of corruption. All this must be proven by the Defendant with a Burden of Evaluation Load System. In the System of Burden of Evidence Purposes, the Obligations of Beneficiaries and Givers is the same that is to prove that what the Prosecutor accused was not true, and therefore the Beneficiary and the Giver must prove that no alleged corruption is committed.

Constraints and difficulties experienced by the State of Indonesia in wiping out corruption crimes not only Political Will Legislator who does not wholeheartedly support, but also the Government's willingness to fight for Reversal Burden of Proof is not persistent enough. Even when the initial proposal for the Reversal of Burden of Evidence, Prof. Oemar Seno Adji (Minister of Justice) rejected it because it is considered contrary to the principle and principle of criminal law, the principle of presumption of innocence or presumption of innocence.

The dynamics of the pros and cons to include the provision of reversing the burden of proof in Act No.20 Of 2001 on the Amendment of Act No.31 Of 1999 on the Eradication of Corruption. In fact, finally it only manifest an unambiguous article because reversing, and the burden of proof is entirely the responsibility and duty of the Prosecutor, but the Defendant has the right to prove that the possessions are not obtained from corruption or not derived from the abuse of power and authority. Such a proof system, according to Mr. Lukman Wiriadinata, called the reversal system of limited burden of proof or presumption of corruption in certain cases. 
In Singapore, it also embraces a limited reversal of burden of proofing or presumption of corruption in certain cases, by including it in part of the offense formulation, such as this example: "Where in any proceedings against a person for an offence under section five or six it is proved that any gratification has been paid or given to or received by a person in the employment of the Government or any department there of or of a public body by or from a person or agent of a person who has or seeks to have any dealing with the Government or any department there of or any public body , that gratification shall be deemed to have been paid or given and received corruptly as an inducement or reward as here in before mentioned unless the contrary is proved ".

Eradicating corruption in Singapore is not too difficult because the issue is not as complicated in Indonesia. Society and Government Officials/Public Officials/Singapore Political Officials already have an orderly culture and mentality, high legal awareness because in Singapore the law is fully enforced, besides the Singapore Government is known as a clean government. Singapore is at the same level as Australia in terms of the number of corruption, because both countries are really committed to running a clean government. The AntiCorruption Agency in Singapore is only a guard dog or watchdog, because in Singapore the Officials and People have a strong religious and cultural spirit to order and not break the law. Orderly is not for fear of criminal sanctions, but orderly because it becomes a pattern and system in the life of the state and society. ${ }^{11}$

In Australia, it has an independent, honest and wellperforming Corruption Eradication Corruption Agency. Anti-corruption education is given to the public in the public sector and its Public Officials, so that corruption eradication is conducted in a systematic and holistic way. Australian views corruption as a behavior that defies honesty and dispels justice. Indonesia is somewhat far behind, about the success of combating corruption in comparison with the two countries.

The State of Australia, in its history is the most corrupt country, but is now the cleanest country, because its Officials are professional, committed not to corrupt, and its citizens are also accustomed to obey the laws, and not to resort to rules that violate the rules, in relation to Officials.

Mental and behavioral conditions Officials and communities in Singapore and Australia are different from the mental and behavioral conditions of Officials and Indonesians. Therefore, certainly to eradicate corruption in Indonesia cannot be as successful as Singapore and Australia. Given that many factors and variables are hindering corruption eradication in Indonesia. The complexity of the corruption issue, one must find one of the most appropriate ways to combat corruption. Law enforcement, as a repressive effort, should emphasize changing the passage that provides assertiveness about the Reversal Transfer Reversal System.

11 Hariman Satria, 2014, Anatomi Hukum Pidana Khusus, UII Press, Yogyakarta, P.49-51 . 
The Reversal Burden Reversal System becomes extremely important and urgent, as with an inverted evidentiary system, making Officials with the potential for corruption to think long. The Burden Reversal System can be used as a vehicle for Officials to be more careful and more honest, not to be deceived by corruption. The Burden Reversal System has a working model that who is accused of corruption, and then he must prove that he is not corrupt. The burden of proof model that must be done by the Defendant is a scourge for anyone who is seeking to corrode.

The Principle of Reversal of Burden charter does, indeed, impose burdens and obligations on the Defendant, who has been the burden and duty of the Prosecutor. Urgency Reversal the burden of this charter is for others to be able to count not to commit corruption, because the proof of corruption must be proven by the person in the indictment by the Prosecutor, that he is not corrupt. The burden of proof with this Reverse Evidence System will certainly alleviate the duties and obligations of the Prosecutor. Such a matter is expected that the Prosecutor will be able and willing to disclose and file as many as the Corruption Defendants in the Court, thus spurring to eradicate corruption eradication in a way that is equal. Such a working model will surely yield good results and in time Indonesia will be free from corruption like neighboring countries like Malaysia, Singapore, Australia and Thailand. ${ }^{12}$

\section{CONCLUSION}

Efforts to combat corruption must be comprehensive, holistic and integrative, since corruption is an extraordinary crime, therefore it must be eradicated in an extraordinary way.

Eradication of corruption must be done simultaneously and sustainable, ranging from prevention as a preventive effort, which is done by strengthening the religious spirituality of the entire Indonesian nation. At the same time, it should also be enhanced repressive eradication of corruption, with law enforcement, which implements the System of Burden Reversal of Evidence (om kering van het bewijslast or shifting burden of proof /reversal burden of proof).

The burden of proof with this system is most effective in reducing the rate of corruption in Malaysia, Australia and Singapore, so that now these Governments are clean, in Indonesia it is necessary to implement the Probability Reversal System (om kering van het bewijslast or shifting burden of proof /reversal burden of proof), so that by 2020 Indonesia will be free and clean from corruption. 


\section{BIBLIOGRAPHY}

Amir Syamsuddin, 2008, Integritas Penegak Hukum, Hakim, Jaksa, Polisi, dan Pengacara, Kompas, Jakarta.

Andi Hamzah, 2014, Perbandingan Pemberantasan Korupsi Di Berbagai Negara, Sinar Grafika, Jakarta.

Duski Ibrahim, 2006, Perumusan Fikih Anti Korupsi, Gama Media, Yogyakarta.

Hariman Satria, 2014, Anatomi Hukum Pidana Khusus, UII Press, Yogyakarta

Heri Junaedi, 2006, Agama Melawan Budaya Korupsi, Gama Media, Yogyakarta.

Junaedi dalam M.Akil Mochtar, 2006, Memberantas Korupsi Efektivitas Sistem Pembalikan Beban Pembuktian Dalam Gratifikasi, Q-Communication, Jakarta

Marwan Efendy, 2013, Korupsi Dan Srategi Nasional Pencegahan Serta Pemberantasannya, Referensi, Jakarta.

Muslich, 2004, Etika Bisnis Is/ami, Ekonisia-F.E.UII, Yogyakarta.

Pulungan Suyuthi, 2006, Korupsi Di Negeri Berpenduduk Mayoritas Muslim : Suatu Kajian Tentang Sistem Politik, Gama Media, Yogyakarta.

Robert Klitgaard, 2001, Membasmi Korupsi, second edition, Yayasan Obor Indonesia, Jakarta 